\title{
Unexpected Histopathological Findings After Laparoscopic Sleeve Gastrectomy
}

\author{
Laparoskopik Sleeve Gastrektomi Ameliyatı Sonrasında Görülen Beklenmedik \\ Histopatolojik Bulgular
}

Burçin Batman, (1) Hasan Altun

İstinye University Faculty of Medicine, Department of General Surgery, i̇stanbul, Turkey

\begin{abstract}
Introduction: The prevalence of obesity is increasing all over the world. Laparoscopic sleeve gastrectomy (LSG) has become the most common bariatric surgery in the world today. Unlike other bariatric surgeries, laparoscopic sleeve gastrectomy yields a pathological examination. The aim of this study was to describe unexpected histopathological findings following LSG. Methods: In this study, the pathologies of 1364 patients who underwent LSG between March 2013 and September 2019 were analyzed retrospectively. Patients were evaluated by a multidisciplinary team in the preoperative period. Patients who met the criteria for LSG were operated. These criteria were; Body Mass index (BMI) $\geq 40 \mathrm{~kg} / \mathrm{m}^{2}$ or $\mathrm{BMI}>35 \mathrm{~kg} / \mathrm{m}^{2}$ and comorbidities or BMI between 30 and $35 \mathrm{~kg} / \mathrm{m} 2$ with accompanying Type 2 diabetes Mellitus or Metabolic syndrome. Two hundred four of the patients underwent gastroscopy preoperatively.
\end{abstract}

Results: One thousand three hundred sixty four patients underwent LSG. The mean age was $40.93 \pm 10.86$ years; 974 patients $(71.48 \%)$ were female. The mean BMI was $42.23 \pm 7.28$. The most common findings in the pathologies were normal gastric specimen (50\%), gastritis (30\%) and changes due to proton pump inhibitor use (23\%) respectively. Conclusion: Gastroscopy should be added to the preoperative preparation process in cases where there is no gastric specimen after the operation. Preoperative gastroscopy is not a necessity for laparoscopic sleeve gastrectomy. It can be performed in selected cases.

Keywords: Laparoscopic sleeve gastrectomy, bariatric surgery, histopathological changes

\section{öZ}

Amaç: Obezite sıklığı tüm dünyada artmaktadır. Laparoskopik sleeve gastrektomi (LSG) günümüzde dünya genelinde en sık uygulanan bariatrik cerrahi olarak yerini almıştır. Diğer bariatrik cerrahilerin aksine LSG'de patolojik inceleme yapılabilecek bir piyes çıkmaktadır. Bu çalıșmanın amacı LSG'yi takiben beklenmeyen histopatolojik bulguları tanımlamaktır.

Yöntem: Bu çalıșmada Mart 2013 ile Eylül 2019 tarihleri arasında LSG uygulanan 1364 hastanın patolojileri geriye dönük olarak incelendi. Hastalar ameliyat öncesi dönemde multidisipliner bir ekip tarafından değerlendirildi. LSG'ye uygun kriterleri sağlayan hastalar Amerikan Metabolik ve Bariatrik Cerrahlar Birliği kriterlerine göre ameliyata alındı. Ameliyat öncesi dönemde 204 hastaya gastroskopi yapıldı. Bulgular: Bin üç yüz altmış dört hastaya LSG uygulandı.

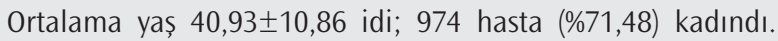
Ortalama Vücut Kitle indeksi 42,23 $\pm 7,28$ idi. Patolojilerdeki en sık bulgu normal mide piyesi (\%50) olmakla birlikte bunu takip eden bulgular gastrit (\%30) ve proton pompa inhibitörü kullanımına bağlı değişikliklerdi (\%23). Sonuç: Sleeve gastrektomi sonrasında beklenmedik histopatolojik bulgular saptanabilir. Ancak ameliyat öncesi yapılan gastroskopi ile saptanması zordur. LSG ameliyatı öncesinde böyle bir zorunluluk olmayıp seçilmiş olgularda ameliyat öncesi dönemde uygulanabilir.

Anahtar Kelimeler: Laparoskopik sleeve gastrektomi, histopatolojik değișiklikler, bariatrik cerrahi
Address for Correspondence/Yazıșma Adresi: Burçin Batman MD, istinye University Faculty of Medicine, Department

of General Surgery, ístanbul, Turkey

Phone: +90 5324715255 E-mail: drburcinbatman@yahoo.com ORCID ID: orcid.org/0000-0003-2245-3337

Cite this article as/Atıf: Batman B, Altun H. Unexpected Histopathological Findings After Laparoscopic Sleeve Gastrectomy. İstanbul Med J 2020; 21(2): 88-91.
Received/Geliş Tarihi: 10.10.2019 Accepted/Kabul Tarihi: 24.01.2020

(C) Copyright 2020 by the University of Health Sciences Turkey, Istanbul Training and Research Hospital/istanbul Medical Journal published by Galenos Publishing House.

(C) Telif Hakkı 2020 Sağgık Bilimleri Üniversitesi İstanbul Ĕğitim ve Araştırma Hastanesi/listanbul Tıp Dergisi, Galenos Yayınevi tarafından basılmıștır. 


\section{Introduction}

The incidence of obesity is increasing worldwide. More than one billion adults are thought to be obese or overweight. Obesity is associated with many diseases, including low life expectancy and arterial hypertension, hyperlipidemia, type 2 diabetes mellitus (T2DM) (1-3).

Bariatric surgery is the most effective technique to improve comorbidities associated with weight loss and obesity (4). Today, laparoscopic sleeve gastrectomy (LSG) is the most commonly applied bariatric surgery for obesity and associated comorbidities in the United States and AsiaPacific region, with its relative ease of application and excellent results $(5,6)$. Unlike Roux-en-Y gastric bypass, a specimen is removed that can be pathologically examined and unexpected pathological results can be encountered.

In most of the previously published series, it was reported that upper gastrointestinal system endoscopy was performed preoperatively, and fewer studies reported that there were few or no endoscopic examinations (7-11). However, this issue is still controversial. Although The American Association of Gastrointestinal and Endoscopic Surgeons and The American Gastrointestinal Endoscopy Society recommend preoperative endoscopy in patients with gastrointestinal symptoms, it is recommended to be performed routinely for all patients that will undergo Roux-en-Y gastric bypass because it is difficult to reach remnant stomach postoperatively (12). Similarly, The American Association of Metabolic and Bariatric Surgeons (ASMBS) recommends gastroscopy only in clinical necessity in the preoperative period (13).

The aim of this study is to identify unexpected histopathological findings following LSG.

\section{Methods}

Pathology reports of patients were retrospectively analyzed to identify all consecutive patients with morbid obesity who underwent LSG between March 2013 and September 2019. All patients were evaluated as suitable for bariatric surgery based on The American Association of Clinical Endocrinologists, The Obesity Association and ASMBS guidelines. Written and verbal surgical informed consent form was obtained from all patients before surgery. Approval was obtained from the ethics committee of Liv Hospital Ulus on 09.08.2019 for this study (decision no: 2019-23).

Patients meeting the following criteria were considered eligible for LSG;

Patients with Body Mass index $(\mathrm{BMI}) \geq 40 \mathrm{~kg} / \mathrm{m}^{2}$ or BMI $>35 \mathrm{~kg} / \mathrm{m}^{2}$ and accompanying comorbidities or BMI between 30 and $35 \mathrm{~kg} / \mathrm{m}^{2}$ and with accompanying T2DM or metabolic syndrome were operated. Patients other than these criteria were not operated. Patients who underwent revision surgery and those who underwent different bariatric procedures were not included in the study.

All patients were evaluated by a multidisciplinary team consisting of a cardiologist, endocrinologist, dietitian, psychologist, pulmonologist and anesthesiologist before surgery. All patients underwent blood tests and a chest X-ray; Abdominal ultrasonography (abdominal pain and/or suspected cholecystitis history) and gastroscopy were also performed in patients who were deemed necessary (reflux, suspected hiatal hernia, upper gastrointestinal system complaints, dyspepsia, family history of malignancy). All patients were examined macroscopically and histopathologically.

\section{Statistical Analysis}

In the statistical analysis of all data, IBM SPSS (Statistical Package for the Social Sciences) Statistics for Windows, Version 22.0. Armonk, NY: IBM Corp. was used. Mean and standard deviation values were calculated in the descriptive statistics of the data.

\section{Results}

Between March 2013 and September 2019, 1425 patients underwent different types of bariatric surgery and 1364 patients who underwent LSG were included in this study. Sixty one cases who were not included in the study were other bariatric surgeries or revision surgeries. The mean age was $40.93 \pm 10.86$ years; 974 patients $(71.48 \%)$ were women. The mean BMI was 42.23 \pm 7.28 .

Most histopathological examinations of the specimens (682 patients, $50 \%$ resulted in normal stomach tissue. The subsequent pathologies were gastritis (409 patients, 30\%) and changes due to proton pump inhibitor (313 patients, 23\%), respectively. Pathologies following them in decreasing rates are Helicobacter pylori (HP) infection (477 patients, $35 \%$ ), intestinal metaplasia (20 patients, 1.5\%), fundic gland polyp (5 patients, 0.36\%), gastrointestinal stromal tumor (GIST) (6 patients, 0.44\%), Schwannoma (1 patient, 0.073\%), heterotopic pancreatic tissue (1 patient, 0.073\%), duplication cyst (1 patient, 0.073\%), and neuroendocrine tumor (1 patient, $0.073 \%$ ) (Table 1). When the age distribution of tumoral results was evaluated, the patient diagnosed with Schwannoma was 49 years old and the tumor diameter was $0.4 \mathrm{~cm}$. In the patients in the GIST group, 2 patients were 45 years old and their tumor diameters were 0.6 and $0.5 \mathrm{~cm}$. One patient was 49 years old and tumor diameter was $1 \mathrm{~cm}$; One patient was 64 years old and tumor diameter was $1.2 \mathrm{~cm}$; one patient was 55 years old and tumor diameter was $0.7 \mathrm{~cm}$; one patient was 56 years old and the tumor diameter was $0.7 \mathrm{~cm}$. The patient with a neuroendocrine tumor was 48 years old and the tumor diameter was $1.2 \mathrm{~cm}$.

Table 1. Histopathological findings

\begin{tabular}{|l|l|}
\hline Normal histopathology & $682(50 \%)$ \\
\hline Gastritis & $409(30 \%)$ \\
\hline $\begin{array}{l}\text { Changes associated with proton pump } \\
\text { inhibitor }\end{array}$ & $313(23 \%)$ \\
\hline Helicobacter pylori (HP) infection & $477(35 \%)$ \\
\hline Intestinal metaplasia & $20(1.5 \%)$ \\
\hline Fundic gland polyp & $5(0.36 \%)$ \\
\hline Gastrointestinal stromal tumor (GIST) & $6(0.44 \%)$ \\
\hline Schwannoma & $1(0.073 \%)$ \\
\hline Heterotopic pancreatic tissue & $1(0.073 \%)$ \\
\hline Duplication cyst & $1(0.073 \%)$ \\
\hline Neuroendocrine tumor & $1(0.073 \%)$ \\
\hline
\end{tabular}


Patients with macroscopically detected pathology during surgery underwent gastroscopy in the surgery. No pathology was found within the lumen.

In the existing cases, no additional treatment was required in the postoperative period. During the preoperative preparation period, 204 (15\%) patients with gastrointestinal system complaints underwent gastroscopy. Medical eradication was not routinely applied to the patients with HP infection.

\section{Discussion}

After the increasing frequency of LSG in recent years, different histopathological results have begun to appear in gastric specimens. This resulted in an increase in parallel with incidental findings.

Although these findings may cause the surgeon to change the way of treatment in the postoperative period, most of the reported diagnoses do not require further clinical follow-up (14). In our series, there was no patient requiring treatment change in the postoperative period.

Some findings may vary according to geographic distributions. For example, the frequency of HP infections can vary from 3.2\% to $64 \%$ (1519,10,20-23). This rate was 35\% in our series. Lee et al. (24) have shown that eradicating HP may reduce the risk of long-term malignancy, but this issue is still controversial. We did not apply routine eradication to patients who did not have clinical complaints among those with HP infection in our clinic.

Neoplasia was a rare finding in both our study and previous studies. While the frequency of GIST ranges from 0 to $1.2 \%(10,11,15,16,19,20,25)$ in the literature, we found $0.44 \%$ in our series. We detected all of these patients during the surgery and there was no need to change the treatment and follow-up protocol both in the surgical technique and in the postoperative period. All of them were early stage stromal tumors with low mitosis rate and low ki67 index. As in the study of Raess et al. (16), these incidentally detected histopathological findings gain more importance in surgical interventions that do not allow upper gastrointestinal system endoscopy in the future and in cases without stomach specimen. Routine gastroscopy in the preoperative period in LSG is a controversial issue. While a group of researchers advocated the necessity of performing routine gastroscopy to each patient preoperatively (26), another group shows a more conservative approach before LSG (27). The fact that we did not encounter any pathology in the gastric lumen in gastroscopy that we performed during the surgery for the lesions we detected incidentally on the stomach wall. This result questions the necessity of preoperative endoscopy.

In our series, we selectively applied upper gastrointestinal system endoscopy in 1364 patients in the preoperative period, as suggested by ASMBS (13), who had suspected hiatal hernia, family history of malignancy, and severe upper gastrointestinal complaints. We performed preoperative endoscopy only in $15 \%$ of patients.

We decided to perform Roux-en-Y gastric bypass instead of LSG upon the detection of grade $C$ esophagitis according to the Los Angeles classification in only one of the patients who underwent gastroscopy in the preoperative period. LSG was applied to all other patients and a routine follow-up protocol was applied in the postoperative period. Although Safaan et al. (19) found an increase in abnormal pathologies detected with increasing age, we did not find any findings increasing with age in our series.

\section{Conclusion}

Preoperative endoscopy should be routinely performed especially in the types of surgery where endoscopic examination cannot be performed after surgery and a gastric specimen will not be removed. However, preoperative endoscopic evaluation is sufficient only in selected cases for LSG, since it does not cause much change in the decision of the type of surgery or in the postoperative follow-up.

Ethics Committee Approval: Approval was obtained from the ethics committee of Liv Hospital Ulus on 09.08.2019 for this study (decision no: 2019-23).

Informed Consent: Written and verbal surgical informed consent form was obtained from all patients before surgery.

Peer-review: Externally peer-reviewed.

Author Contributions: Concept - H.A.; Design - B.B.; Data Collection and/or Processing - B.B.; Analysis and/or Interpretation - H.A.; Literature Search - H.A.; Writing - B.B.

Conflict of Interest: No conflict of interest was declared by the authors.

Financial Disclosure: The authors declared that this study received no financial support.

\section{References}

1. Gami AS, Witt BJ, Howard DE, Erwin PJ, Gami LA, Somers VK, et al. Metabolic syndrome and risk of incident cardiovascular events and death: a systematic review and meta-analysis of Iongitudinal studies. J Am Coll Cardiol 2007; 49: 403-14.

2. Klijs B, Mackenbach JP, Kunst AE. Obesity, smoking, alcohol consumption and years lived with disability: a Sullivan life table approach. BMC Public Health 2011; 11: 378

3. Whitlock G, Lewington S, Sherliker P, Clarke R, Emberson J, Halsey J, et al. Body mass index and cause-specific mortality in 900,000 adults: collaborative analyses of 57 prospective studies. Lancet 2009; 373: 1083-96.

4. Colquitt JL, Pickett K, Loveman E, Frampton GK. Surgery for weight loss in adults. Cochrane Database Syst Rev 2014; CD003641.

5. D'Hondt M, Vanneste S, Pottel H, Devriendt D, Van Rooy F, Vansteenkiste F. Laparoscopic sleeve gastrectomy as a single-stage procedure for the treatment of morbid obesity and the resulting quality of life, resolution of comorbidities, food tolerance, and 6-year weight loss. Surg Endosc 2011; 25: 2498-504.

6. Marceau P, Biron S, Bourque RA, Potvin M, Hould FS, Simard S. Biliopancreatic diversion with a new type of gastrectomy. Obes Surg 1993; 3: 29-35.

7. Miller GC, Reid AS, Brown IS. The pathological findings seen in laparoscopic sleeve gastrectomies for weight loss. Pathology 2016; 48: 228-32

8. Kinsinger LA, Garber JC, Whipple O. A review of sleeve gastrectomy specimen histopathology. Am Surg 2016; 82: 1101-4.

9. AbdullGaffar B, Raman L, Khamas A, AlBadri F. Should we abandon routine microscopic examination in bariatric sleeve gastrectomy specimens? Obes Surg 2016; 26: 105-10. 
10. Dogan U, Suren D, Oruc MT, Gokay AA, Mayir B, Cakir T, et al. Spectrum of gastric histopathologies in morbidly obese Turkish patients undergoing laparoscopic sleeve gastrectomy. Eur Rev Med Pharmacol Sci 2017; 21: 5430-6.

11. Yardimci E, Bozkurt S, Baskoy L, Bektasoglu HK, Gecer MO, Yigman S. Rare entities of histopathological findings in 755 sleeve gastrectomy cases: a synopsis of preoperative endoscopy findings and histological evaluation of the specimen. Obes Surg 2018; 28: 1289-95

12. ASGE STANDARDS OF PRACTICE COMMITTEE, Anderson MA, Gan SI, Fanelli $\mathrm{RD}$, Baron TH, Banerjee S, Cash BD, et al. Role of endoscopy in the bariatric surgery patient. Gastrointest Endosc 2008; 68: 1-10.

13. Mechanick JI, Youdim A, Jones DB, Garvey WT, Hurley DL, McMahon MM, et al. Clinical practice guidelines for the perioperative nutritional, metabolic, and nonsurgical support of the bariatric surgery patient-2013 update: cosponsored by American association of clinical endocrinologists, the obesity society, and American society for metabolic \& bariatric surgery. Surg Obes Relat Dis 2013; 21 Suppl 1: S1-27.

14. Oner RI, Ozdas S. Histopathological findings in morbid obese patients undergoing laparoscopic sleeve gastrectomy: does $\mathrm{H}$. pylori infection effective on pathological changes? Obes Surg 2018; 28: 3136-41.

15. Almazeedi S, Al-Sabah S, Al-Mulla A, Al-Murad A, Al-Mossawi A, Al-Enezi K, et al. Gastric histopathologies in patients undergoing laparoscopic sleeve gastrectomies. Obes Surg 2013; 23: 314-9.

16. Raess PW, Baird-Howell M, Aggarwal R, Williams NN, Furth EE. Vertical sleeve gastrectomy specimens have a high prevalence of unexpected histopathologic findings requiring additional clinical management. Surg Obes Relat Dis 2015; 11: $1020-3$.

17. Ohanessian SE, Rogers AM, Karamchandani DM. Spectrum of gastric histopathologies in severely obese American patients undergoing sleeve gastrectomy. Obes Surg 2016; 26: 595-602
18. Lauti M, Gormack SE, Thomas JM, Morrow JJ, Rahman H, Mac- Cormick AD. What does the excised stomach from sleeve gastrectomy tell us? Obes Surg 2016; 26: 839-42.

19. Safaan T, Bashah M, El Ansari W, Karam M. Histopathological changes in laparoscopic sleeve gastrectomy specimens: prevalence, risk factors, and value of routine histopathologic examination. Obes Surg 2017; 27: 1741-9.

20. Aljerian K. Histopathological findings in laparoscopic sleeve gastrectomy specimens from patients with obesity in Saudi Arabia. Gastroenterol Res Pract 2018; 2018: 1702705

21. Brownlee AR, Bromberg E, Roslin MS. Outcomes in patients with Helicobacter pylori undergoing laparoscopic sleeve gastrectomy. Obes Surg 2015; 25: 2276-9.

22. Rath-Wolfson L, Varona R, Bubis G, Tatarov A, Koren R, Ram E. Gastritis in patients undergoing sleeve gastrectomy: prevalence, ethnic distribution, and impact on glycemic. Medicine (Baltimore) 2017; 96: e6602.

23. Rossetti G, Moccia F, Marra T, Buonomo M, Pascotto B, Pezzullo A, et al. Does helicobacter pylori infection have influence on outcome of laparoscopic sleeve gastrectomy for morbid obesity? Int J Surg 2014; 12 Suppl 1: S68-71

24. Lee YC, Chiang TH, Chou CK, Tu YK, Liao WC, Wu MS, et al. Association between Helicobacter pylori eradication and gastric cancer incidence: a systematic review and metaanalysis. Gastroenterology 2016; 150: 1113-24.e5

25. Clapp B. Histopathologic findings in the resected specimen of a sleeve gastrectomy. JSLS 2015;19: e2013.00259

26. Peker KD, Sahbaz NA, Seyit $\mathrm{H}$, Kones $\mathrm{O}$, Gumusoglu AY, Alis $\mathrm{H}$. An alternative view on the necessity of EGD before sleeve gastrectomy. Surg Obes Relat Dis 2017; 13: 1959-64.

27. Salama A, Saafan T, El Ansari W, Karam M, Bashah M. Is routine preoperative esophagogastroduodenoscopy screening necessary prior to laparoscopic sleeve gastrectomy? Review of 1555 cases and comparison with current literature. Obes Surg 2018; 28: 52-60. 